\title{
Cardiac perfusion screening in patients to be treated with radiation therapy in the chest, is it a must?
}

\author{
Leo H. B. Baur
}

Received: 13 April 2009/Accepted: 13 April 2009/Published online: 12 May 2009

(C) The Author(s) 2009. This article is published with open access at Springerlink.com

Radiation therapy has been used for treatment of cancer for a long time [1]. In the thoracic region, it is frequently used for management of Hodgkin and nonHodgkin lymphoma, lung cancer, esophageal cancer, breast cancer, thymoma and other malignancies in the thorax. The management of these malignancies has undergone a major evolution during the last decades. The majority of cancer patients now undergo some form of combined radiation and chemotherapy. Initially the heart was thought to be relatively resistant to radiation induced injury but the lately the existence of radiation-induced heart disease has been established [2]. Due to the success of radiation and chemotherapy there is a growing cohort of survivors of cancers who are at risk for the complications of radiation therapy of the chest. These complications include arm edema, pneumonitis, rib fractures, brachial plexopathy, secondary malignancies and cardiac toxicity. Unfortunately, radiation can damage any component of the heart. Pericarditis is a typical early complication, with dense collagen and fibrin replacement of the adipose tissue. Also coronary artery disease, cardiomyopathy,

Editorial comment to the article of Gayed et al. (doi: 10.1007/s10554-009-9440-7).

L. H. B. Baur $(\bowtie)$

Atrium Medical Centre Parkstad,

University of Maastricht, Henri Dunantstreet 5, 6401 CX Heerlen, The Netherlands

e-mail: 1br01@atriummc.nl valvular heart disease and conduction abnormalities can occur years after radiation treatment [3]. The histologic findings of radiation induced cardiotoxicity are diffuse interstitial fibrosis and narrowing of arterial vessels and capillaries [4]. There is a 50\% reduction of the ratio of capillaries to myocytes which in turn results in myocardial cell death, ischemia and fibrosis. Radiation also causes injury of the coronary artery endothelial cells. It causes fibro-intimal hyperplasia, which in turn leads to thrombus formation and lipid deposition [5]. In some cases coronary spasm may occur [6].

Radiation therapy ultimately can result in coronary artery disease, fibrotic changes of cardiac leaflets or valves, diastolic function and cardiac arrhythmias [7-11]. Risk factors for radiation induced cardiac toxicity are total radiation dose, radiation dose per fraction, the volume of the heart exposed to radiation and the concomitant administration of cardiotoxic chemotherapy like anthracyclines and trastuzumab. The paper of Gayed et al. in the present issue of the International Journal of Cardiac Imaging addresses an important clinical issue of patients who survived esophageal and lung cancer [12]. The authors show that one-third of the patients who received radiation therapy with the heart in the radiation field developed cardiac ischemia. Even more patients developed cardiac complications and cardiac death. Although cardiac ischemia was frequently seen, it was not predictive for future cardiac complications. In a multivariate analysis, a history or the presence of 
arrhythmias and a history of congestive heart failure was associated with cardiac complications. Most of the patients with cardiac ischemia did not have anginal complaints. These findings are in agreement with the study of Marks et al. [9], Heidenreich et al. $[13,14]$ and the Dutch Late Effects Breast Cancer Cohort, which studied the effects of cardiovascular toxicity of radiation therapy in women with breast cancer during a period of 10 years $[15,16]$ and the SEER database [17]. The latter was a large study of women, who survived breast cancer treated with radiation therapy. It showed, that after irradiation the risk of myocardial infarction, angina pectoris and heart failure was increased compared to the women without breast cancer.

The sample size in the study of Gayed was too small and the follow-up time too limited to draw conclusions if silent ischemia detected on myocardial perfusion imaging was predictive for cardiovascular events in this patient population. However, studies in patients with coronary artery disease have shown adverse outcome related to the episodes of asymptomatic cardiac ischemia [18]. In a retrospective review of patients treated with radiation therapy for Hodgkin's disease a relative risk for fatal myocardial infarction of 41.5 over the age-matched general population was shown. Death frequently occurred long (3-22 years) after exposition to radiation [19].

Doctors who take care of patients with cancer who have to be treated or have been treated with radiotherapy of the chest should be aware of the cardiac risks of irradiation. The clinical implication of myocardial perfusion imaging in this group of patients has to be established in large trials with a long follow-up of at least 5-10 years.

Open Access This article is distributed under the terms of the Creative Commons Attribution Noncommercial License which permits any noncommercial use, distribution, and reproduction in any medium, provided the original author(s) and source are credited.

\section{References}

1. Pierce LJ, Hayes DF, Wazer DF, Savarese DMF (2008) Techniques and complications of breast and chest wall irradiation for early stage breast cancer. UptoDate 2008

2. Hancock SL, Tucker MA, Hoppe RT (1993) Factos affecting late mortality from heart disease after treatment for Hodgkin's disease. JAMA 270:1949-1955
3. Marks LB, Constine LS, Adams MJ, Kavanagh B, McKenna WJ, Ross ME (2008) Cardiotoxicity of radiation therapy for malignancy. UptoDate 2008

4. Cuzick J, Stewart H, Rutqvist L, Houghton J, Edwards R, Redmond C, Peto R, Baum M, Fisher B, Host H et al (1994) Cause specific mortality in long-term survivors of breast cancer who participated in trials of radiotherapy. J Clin Oncol 12:447-453

5. Adams MJ, Constine LS, Lipshultz SE (2001) Radiation. In: Crawford MH, DiMarco JP et al (eds) Cardiology. Mosby, London, Chap 8, pp 15.1-15.8

6. Marti V, Garcia J, Auge JM, Obrador D, Ballester M (1991) Coronary arterial spasm and cardiac arrest following mediastinal radiation therapy for Hodgkin's disease. Chest 100:1180-1181

7. Hull MC, Morris CG, Pepine CJ, Mendenhall NP (2003) Valvular dysfunction and carotid, subclavian, and coronary artery disease in survivors of Hodgkin lymphoma treated with radiation therapy. JAMA 290:2831-2837

8. Early Breast Cancer Trialist' Collaborative Group (2000) Favourable and unfavourable effects on long term survival of radiotherapy for early breast cancer: an overview of the randomized trials. Lancet 355:1757-1770

9. Marks LB, Yu X, Prosnitz RG, Zhou SM, Hardenbergh $\mathrm{PH}$, Blazing $\mathrm{M}$, Hollis D, Lind P, Tisch A, Wong TZ, Borges-Neto S (2005) The incidence and functional consequences of RT-associated cardiac perfusion defects. Int J Radiat Oncol Biol Phys 63:214-223

10. Heidenreich PA, Hancock SL, Vagelos RH, Lee BK (2005) Schnittger I diastolic dysfunction after mediastinal irradiation. Am Heart J 150:977-982

11. Larsen RL, Jakacki RI, Vetter VL, Meadows AT, Silber JH, Barber G (1992) Electrocardiographic changes and arrhythmias after cancer therapy in children and young adults. Am J Cardiol 70:73-77

12. Gayed I, Gohar S, Liao Z, McAleer M, Bassett R, Yusuf SW (2009) The clinical implications of myocardial perfusion abnormalities in patients with esophageal or lung cancer after chemoradiation therapy. Int $\mathrm{J}$ Cardiovasc Imaging. doi: 10.1007/s10554-009-9440-7

13. Heidenreich PA, Schnittger I, Strauss HW, Vagelos RH, Lee BK, Mariscal CS, Tate DJ, Horning SJ, Hoppe RT, Hancock SL (2007) Screening for coronary artery disease after mediastinal irradiation for Hodgkin's disease. J Clin Oncol 25:3-5

14. Heidenreich PA, Hancock SL, Lee BK, Mariscal CS, Schnittger I (2003) Asymptomatic cardiac disease following mediastinal irradiation. J Am Coll Cardiol 42:743-749

15. Hooning MJ, Aleman BM, van Rosmalen AJ, Kuenen MA, Klijn JG, van Leeuwen FE (2006) Cause-specific mortality in long-term survivors of breast cancer: A 25-year followup study. Int J Radiat Oncol Biol Phys 64(4):1081-1091

16. Hooning MJ, Botma A, Aleman BM, Baaijens $\mathrm{MH}$, Bartelink H, Klijn JG, Taylor CW, van Leeuwen FE (2007) Long-term risk of cardiovascular disease in 10-year survivors of breast cancer. J Natl Cancer Inst 99(5):365-375

17. Darby SC, McGale P, Taylor CW, Peto R (2005) Longterm mortality from heart disease and lung cancer after radiotherapy forearly breast cancer: prospective cohort study of about 300, 000 women in US SEER cancer registries. Lancet Oncol 6:557-565 
18. Pepine CJ, Sharaf B, Andrews TC, Forman S, Geller N, Knatterud G, Mahmarian J, Ouyang P, Rogers WJ, Sopko G, Steingart R, Stone PH, Conti CR, ACIP Study Group (1997) Relation between clinical, angiographic and ischemic findings at baseline and ischemia-related adverse outcomes at 1 year in the Asymptomatic Cardiac Ischemia Pilot study. J Am Coll Cardiol 7:1483-1489

19. Hancock SL, Donaldson SS, Hoppe RT (1993) Cardiac disease following treatment of Hodgkin's disease in children and adolescents. J Clin Onocol 11:1033-1038 